\title{
Ostańce i miejskie legendy - losy pozostałości po prawosławnej katedrze p.w. Aleksandra Newskiego w Warszawie
}

\author{
Andrzej Golimont \\ Chrześcijańska Akademia Teologiczna w Warszawie, Polska \\ ORCID: 0000-0002-6659-1603 \\ agolimont@gmail.com
}

\begin{abstract}
A. Golimont, Salvages and urban legends -fate of the remnants of Alexander Nevsky cathedral in Warsaw, Elpis, 22 2020: 69-77.
Abstract: In June 2020, 100 years have passed since the actual start of the demolition of the Orthodox cathedral of St. Alexander Nevsky in Warsaw. The largest Orthodox temple in Poland has been open to the faithful for 3 years only. However, it has become legendary like no other, because of its "second life" - the fate of the cathedral's equipment and usage of materials obtained during its demolition. The author describes ambiguous history of the fate of movable equipment and elements of decor of the temple, presenting examples of it further usage. Referring to the example of an iconostasis from an Orthodox church in Krzemien in Belarus, author shows the emerging "urban legends" regarding the use of equipment from the capital's cathedral.

Streszczenie: W czerwcu 2020 roku minęło 100 lat od faktycznego rozpoczęcia burzenia prawosławnej katedry pod wezwaniem św. Aleksandra Newskiego w Warszawie. Ta - największa w Polsce - świątynia prawosławna służyła wiernym zaledwie 3 lata. Jak żadna inna cerkiew obrosła jednak legendami. Zwłaszcza w zakresie jej „drugiego życia”, czyli losów wyposażenia soboru oraz wykorzystania pochodzących z jego burzenia materiałów. Autor opisuje zarówno niejednoznaczną historię losów wyposażenia ruchomego świątyni, jak i elementów jej wystroju. Na przykładach prezentuje losy materiałów budowlanych i wykończeniowych pozyskiwanych z soboru. Odwołując się do przykładu ikonostasu z cerkwi w Krzemieniu na Białorusi, autor pokazuje tworzące się „miejskie legendy” dotyczące wykorzystania sprzętów ze stołecznej katedry.
\end{abstract}

Keywords: Ortodox church, Warsaw, iconostasis, Alexander Nevsky

Słowa kluczowe: sobór, Warszawa, ikonostas, Aleksander Newski

W czerwcu 2020 roku minęło dokładnie 100 lat od dnia, gdy Sejm Rzeczypospolitej Polskiej - po burzliwej dyskusji - postanowił o rozpoczęciu pierwszego etapu burzenia, poświęconej zaledwie 8 lat wcześniej, katedralnej cerkwi pod wezwaniem Aleksandra Newskiego w Warszawie (Sprawozdanie stenograficzne ze 152 posiedzenia Sejmu Ustawodawczego z dnia 1 czerwca 1920 roku, 2020). Wprawdzie względy polityczne zdecydowały, iż wykonanie decyzji ograniczono wówczas do rozebrania dzwonnicy, ale nie było dla nikogo tajemnicą, iż na całość soboru niebawem także przyjdzie czas. Realizując decyzję sejmową, 28 lutego 1923 r., kierowana przez gen. Władysława Sikorskiego Rada Ministrów zdecydowała o zburzeniu So-

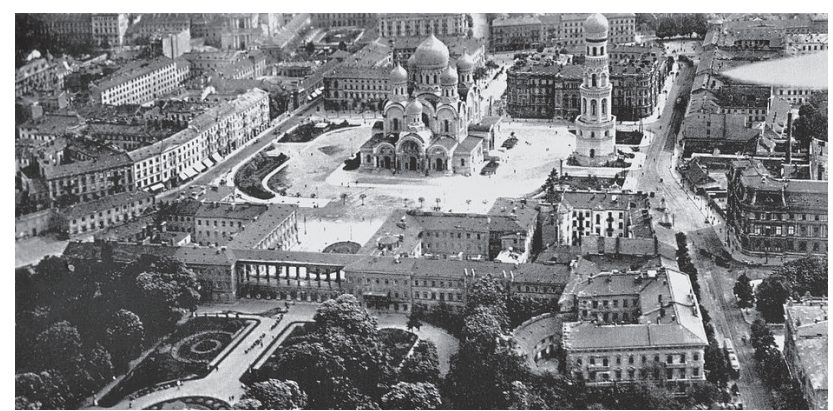

Sobór św. Aleksandra Newskiego w Warszawie około 1914 roku. Zdjęcie lotnicze (ze zbiorów archiwum Warszawskiej Metropolii Prawosławnej). boru (Monitor Polski, 49 1923, s. 1). Do prac przystąpiono wiosną następnego roku, by zakończyć je jesienią 1926.

Paradoksem jest, iż świątynia ta - funkcjonująca w swej założonej formie przez niespełna trzy lata, a następnie służąca wiernym Kościołów luterańskiego i katolickiego - wciąż budzi spore zainteresowanie i obecna jest $\mathrm{w}$ życiu publicznym poprzez $\mathrm{z}$ jednej strony, opowieści o jej artystycznym bogactwie, z drugiej zaś opowieści o losach pochodzących z niej materiałów. Tylko niewielka część z nich jest prawdziwa. Większość uznać należy za „miejską legendę”. Kolejne lata przynoszą coraz to nowe rewelacje. Odkrywane są kolejne „zachowane” fragmenty wystroju katedry. Szybko okazuje się jednak, że ich pochodzenie jest zupełnie inne od przypisywanego, a legendy bardzo daleko mijają się z prawdą.

W niniejszym artykule spróbujemy odpowiedzieć na pytanie: co naprawdę stało się z materiałami pochodzącymi z rozbiórki soboru? Jaki los spotkał jego wyposażenie?

\section{Rozbiórka katedry - materiały budowlane}

Główny autor scenariusza prac rozbiórkowych Tomasz Grzywiński - jeszcze w 1924 roku - pisał do Mini- 


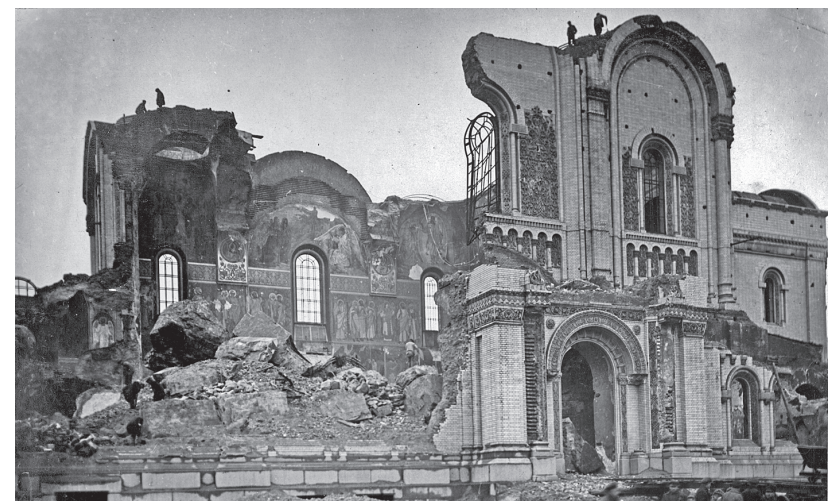

Burzenie soboru w roku 1925. Na ścianie frontowej widoczne otwory po nieskutecznie odpalonych ładunkach wybuchowych (ze zbiorów archiwum Warszawskiej Metropolii Prawostawnej).

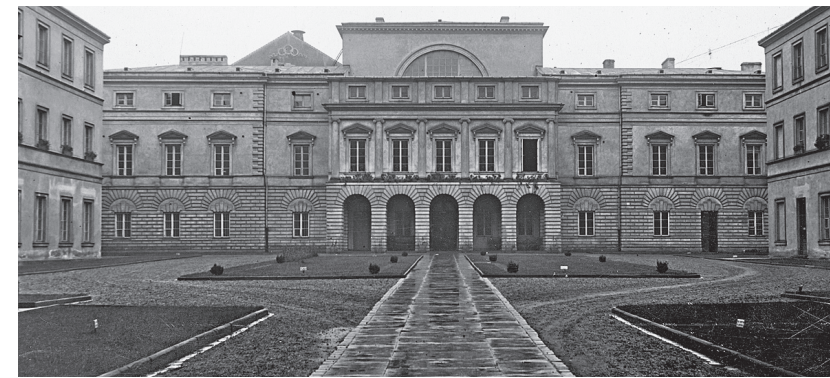

Dziedziniec Pałacu Paca wytożony płytami granitowymi pochodzacymi ze ścian soboru. Rok 1934 (fot. Leon Jarumski, ze zbiorów Narodowego Archiwum Cyfrowego).

sterstwa Robót Publicznych, iż: „Po zburzeniu b. soboru oprócz zasadniczych materjatów budowlnaych otrzyma się pokaźna ilość cegiet ozdobnych, ptyt fajansowych, sztukaterji $i$ majolik, które $w$ budownictwie użytkowem praktycznie nie znajda zainteresowania" (Projekt kościót$k a, 40$ 1924, s. 3). W opinii inż. Grzywińskiego należy wykorzystać ów materiał do budowy na stokach Cytadeli "kościółka-mauzoleum okolonego stylowym cmentarzykiem" (Kurjer Warszawski, 320 1923, s. 3). Z pomysłu - trzeba przyznać dość monstrualnego - nic nie wyszło, bowiem najpierw Ministerstwo zastanawiało się, czy aby "marmury i inne detale (...) moga być zastosowane bez ujmy dla stylów architektonicznych przyjętych $w$ kościotach rz-katolickich" (Kurjer Warszawski, 320 1923, s. 3), a następnie z usług inż. Grzywińskiego zrezygnowano. Materiały z rozbiórki postanowiono zaś wykorzystać na bieżące potrzeby Warszawy.

Od chwili rozpoczęcia rozbiórki materiały z niej pochodzące traktowane były jako swoisty magazyn zaopatrujący nie tylko Warszawę, ale także inwestycje prowadzone daleko poza jej granicami. W swoim sprawozdaniu za lata 1926-27 stołeczny magistrat raportował lapidarnie: ,z uzyskanego materjatu wygruzowano jezdnie i chodniki na 50 przeszło ulicach na peryferjach miasta oraz urzadzono uliczki w parkach i ogradach miejskich, jak równiez boiska sportowe" (Sprawozdanie z działalności Zarzadu m.st. Warszawy za rok 1926 i I kwartat 1927, 1928, s. 130). Dwa lata później, gdy rozbiórka była już ostatecznie ukończona, a Plac Saski uporządkowany podsumowywano, iż „ogółem z rozbiórki otrzymano 38000 metrów sześc. gruzu, z któ-

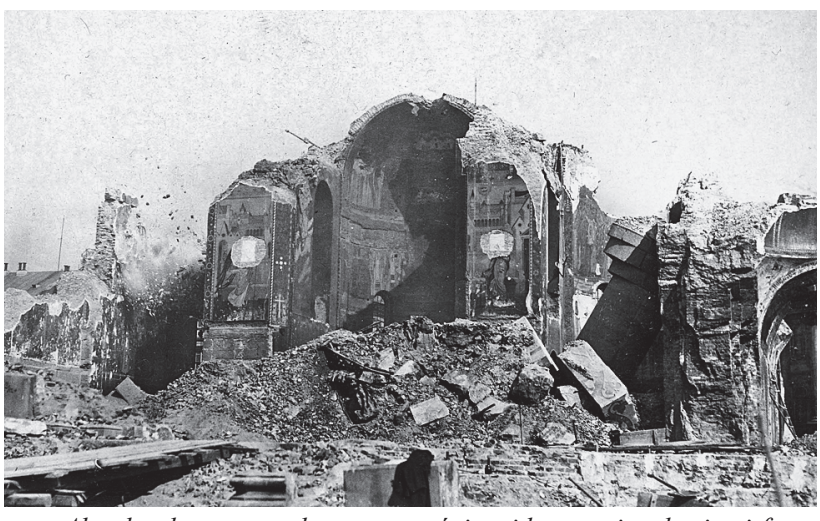

Absyda oltarzowa soboru z wyraźnie widocznymi wykuciami fragmentów mozaiki Wasniecowa (ze zbiorów archiwum Warszawskiej Metropolii Prawosławnej).

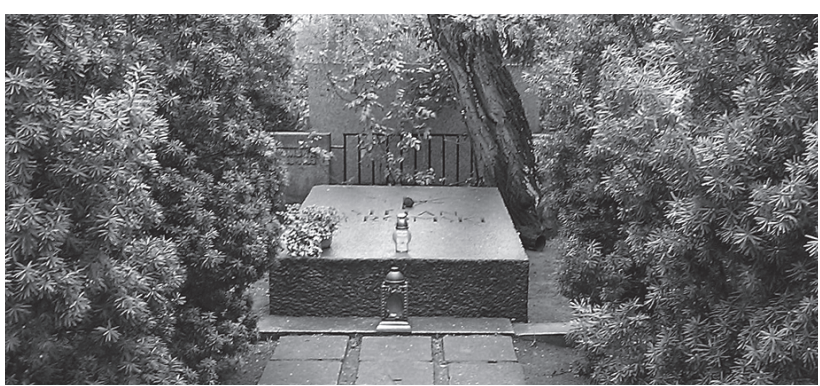

Grobowiec Stefana Żeromskiego na cmentarzu Ewangelicko-Reformowanym $w$ Warszawie (fot. ze zbiorów prywatnego archiwum Barbary Wachowicz).

rego wykonano 82.500 metrów kw. jezdni, 37.500 metrów kw. chodników i 47.500 metrów kw. alei i dróżek w parkach miejskich. Nadto $1.800 \mathrm{~m}$. sześc. użyto na obsypywanie filarów mostowych, a 3.000 m. sześc. przyznano różnym instytucjom państwowym i społecznym" (Kurjer Warszawski, 45, 1929, s. 5).

$\mathrm{Z}$ materiału pochodzącego z burzonej świątyni utwardzić miano m.in. ulice Szlachecką, Wschową, Karlińskiego, Gumińską, Teresińską, Polkowską, Kwiatową, Krożańską, Nowosielecką, Lewicką, Racławicką, Płocką i Iwicką (290 robotników robi dziennie 150 dziur $w$ soborze, 1926, s. 4). Jeśli tak się stało, to znaczna część tego materiału - zwłaszcza na ulicach Iwickiej, Płockiej oraz Racławickiej - pozostała do dziś, bowiem ich przebieg się nie zmienił, a prowadzone przez lata powojenne prace modernizacyjne nigdy nie obejmowały wymiany tzw. twardej podbudowy.

Nie można jednak mieć pewności, iż gruz na te ulice rzeczywiście trafił. Informacje zawarte w magistrackim sprawozdaniu podważane były przez prasę jeszcze w 1926 roku. Oto na przykład lipcu 1926 roku „Kurjer Poranny” donosił: (...) pewnego dnia, na ulice te zajechaty auta magistrackie, zabierając gruz z powrotem. Gdzieniegdzie „dla przyzwoitości” wytożono nim uprzednio kawatek jezdni czy chodnika, w rozmiarach oczywiście minimalnych, reszta zaś ku rozpaczy mieszkańców wywędrowała z przedmieść w niewiadomym kierunku. O faktach podobnych, dochodza nas głosy z różnych przedmieść Warszawy. Zaobserwowano je i w Mokotowie i na Woli, w kilku punktach, że zawsze gruz wywożony byt z tych ulic, które naj- 
bardziej odczuwaty konieczność uregulowania ,,stosunków brukarskich" (Kurjer Poranny, 206 1926, s. 5).

Sprawozdanie to nie uwzględnia także samowoli „przedsiębiorczych” mieszkańców Warszawy, którzy przy okazji rozbiórki soboru postanowili skorzystać z łatwego i najwyraźniej niezbyt dobrze pilnowanego majątku. Sporym echem odbiła się sprawa niejakiego Władysława Guły, który będąc zatrudnionym przy pracach rozbiórkowych, miał przewozić gruz nad Wisłę, by umacniać nim brzegi (Podstępna sprzedaż domu zbudowanego z cegiet soboru, 1935, s. 7). Okazało się, że znaczną jego część przewiózł dokładnie w przeciwnym kierunku - na ul. Belwederska - gdzie zbudował sobie mily, piętrowy domek. Sprawa prawdopodobnie nie wyszłaby na jaw, gdyby w 1934 roku nie postanowił domu tego wymienić na majątek ziemski Olejniczaków pod Łodzią. Transakcją zainteresowała się prokuratura, która przy okazji ujawniła źródło cegieł wykorzystanych do budowy. Ile było jeszcze takich Gułów trudno stwierdzić.

Nie ulega natomiast wątpliwości, iż fragmenty murów Soboru da się dziś odnaleźć także w części alejek Ogrodu Saskiego. Aż do 1926 roku ów „salon Warszawy” nie posiadał utwardzonych dróżek, co powodowało, iż - jak utyskiwała prasa - ,podczas niepogody nawierzchnia alei przemieniała się w błotnista i lepka katużę, po której publiczność brnęła po kostki" (Przegląd Wieczorny 51 1926, s. 2). W ciągu kilku miesięcy zaledwie, zatrudniając bezrobotnych opłacanych ze specjalnego funduszu, utwardzono wszystkie ciągi komunikacyjne parku. Część ówczesnego materiału wykorzystano w czasie powojennej rewaloryzacji Parku jako podbudowę nowych ścieżek.

Kilkaset metrów kwadratowych zdemontowanych płyt granitowych użyto do poprawienia estetyki wejścia do mieszczącego się w Pałacu Paca przy ul. Miodowej 15 Sądu Okręgowego (Express Poranny, 274 1927, s. 7). Wybudowano z nich szeroką aleję łączącą bramę wjazdową z głównym wejściem do budynku. W czasie II wojny światowej Pałac Paca wprawdzie znacznie ucierpial, ale, jak wskazują zachowane zdjęcia, owa reprezentacyjna aleja przetrwała. Zastąpiono ją nową, piaskowcową prawdopodobnie dopiero w końcowej fazie remontu Pałacu w 1951 roku.

Sobór św. Aleksandra wyposażony był - co na początku XIX wieku było w Warszawie wciąż jeszcze rzadkością - w dwa wynalazki: elektryczność oraz system centralnego ogrzewania. W specjalnie $\mathrm{w}$ tym celu wybudowanym tuż koło Pałacu Kronenbergów niewielkim budyneczku na tyłach świątyni - oznaczonym jako Książęca 13 umieszczono „kottownie do wytwarzania sztucznego ogrzewania $i$ wentylacji soboru oraz machiny do oświetlenia elektrycznego tegoż. Budynki te z soborem połaczono tunelem w poprzek ulicy Królewskiej, który przeszedt pod gmachem, przeznaczonym na rozbiórke, a dawniej klubu myśliwskiego" (Kurjer Polski, 311 1902, s. 2) (Z kronikarskiego obowiązku odnotujmy, że budynek ten służył także jako służbowe mieszkanie dla dzwonnika katedralnego). Całe wyposażenie kotłowni oraz znaczną część instalacji grzewczej wymontowano zaraz na początku grabieży soboru i przekaza- no do Szpitala Ujazdowskiego, który od 1918 roku nosił dumną nazwę Głównego Szpitala Wojskowego (Historia jednego podwórka, 16 1926, s. 3). We wrześniu 1939 roku znaczna część szpitala została zniszczona, a to, co ocalało, zburzono w sierpniu 1944 roku.

Najbardziej wartościowe materiały kamienne uzyskane z burzenia Soboru wykorzystywane były przez władze jako doskonały materiał do bieżącej działalności polityczno-rzeźbiarskiej.

Wymiar symboliczny miało użycie „marmurów i kamieni, wydobytych z dawnej cerkwi prawosławnej, która umyślnie dla zgubienia duszy polskiej zbudowat na placu Saskim, niejako na środku miasta, prześladowca naszego narodu, jenerat gubernator Hurko" (Orzeł Biały, 45 1925, s. 5) przy realizowaniu zaprojektowanego przez Stanisława Kazimierza Ostrowskiego Grobu Nieznanego Żołnierza. Podobnie traktować należy użycie 4 nefrytowych kolumn do wybudowania imponującego wejścia do wawelskiej krypty, w której pochowano marszałka Józefa Piłsudskiego. Miało to symbolizować ostateczne zwycięstwo nad zaborcą. Nie tylko unicestwienie, zwycięstwo za życia, ale i po śmierci. Teraz ciemiężyciel sam będzie służył.

Granitowy materiał - przekazany na osobiste polecenie Prezydenta Warszawy Zygmunta Słomińskiego, posłużył w 1927 roku do stworzenia nagrobka Stefana Żeromskiego na stołecznym cmentarzu Ewangelicko-Reformowanym przy ul. Żytniej (Kurjer Warszawski, 320 1927, s. 2). Elementy te przetrwały pożogę II wojny światowej i oglądać można je do dziś.

W 1929 roku Zarząd Miasta Stołecznego Warszawy postanowił zlecić rzeźbiarzowi Janowi Biernackiemu wykonanie fontanny w Parku Skaryszewskim. Dla obniżenia kosztów zobowiązano artystę do uwzględnienia w projekcie wykorzystania materiałów pochodzących z rozbiórki Soboru (Kurjer Poranny, 120, 1929, s. 5). Artysta wykorzystał więc ciosy polerowanego granitu - będące prawdopodobnie fragmentami mniejszych kolumn świątyni. Rzeźbę umieszczono nieopodal kortów tenisowych w 1930 roku, niestety nie przetrwała II wojny.

Przetrwała natomiast część granitowego cokołu pomnika Jana Kilińskiego (Kurjer Warszawski, 100 1934, s. 4) wystawionego według projektu Stanisława Jackowskiego na stołecznych murach obronnych.

\section{Wystrój wewnętrzny mozaiki i freski}

Przystępując do burzenia soboru zarówno władze państwowe, jak i miejskie zapowiadały, iż wszystkie elementy wystroju (a te w większości nawet przez zagorzałych zwolenników zburzenia świątyni uważane były za niezwykle wartościowe artystycznie) zostaną zachowane z najwyższą pieczołowitością. Toczono wprawdzie dyskusję czy powinny następnie trafić do dyspozycji Cerkwi, muzeów czy też posłużyć jako elementy wystroju nowych zamierzeń inwestycyjnych, ale co do konieczności ich ocalenia osiągnięto konsensus. 


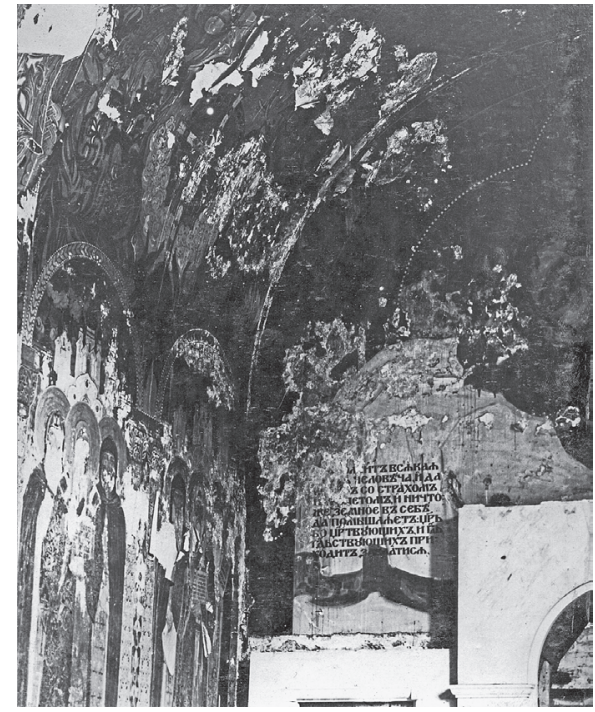

Uszkodzone przez wilgoć freski na ścianie soboru stan $w$ roku 1923, przed przystapieniem do burzenia światyni (ze zbiorów archiwum Warszawskiej Metropolii Prawosławnej).

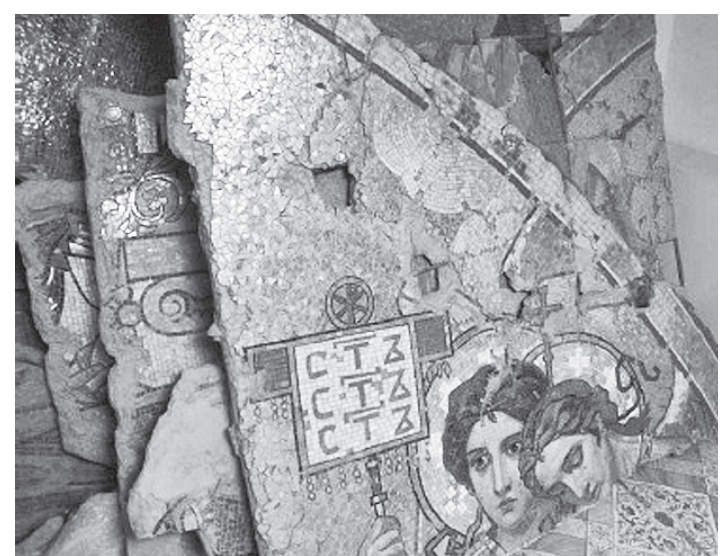

Niewykorzystane fragmenty mozaiki przywiezione z Warszawy i przechowywane w cerkwi w Baranowiczach.

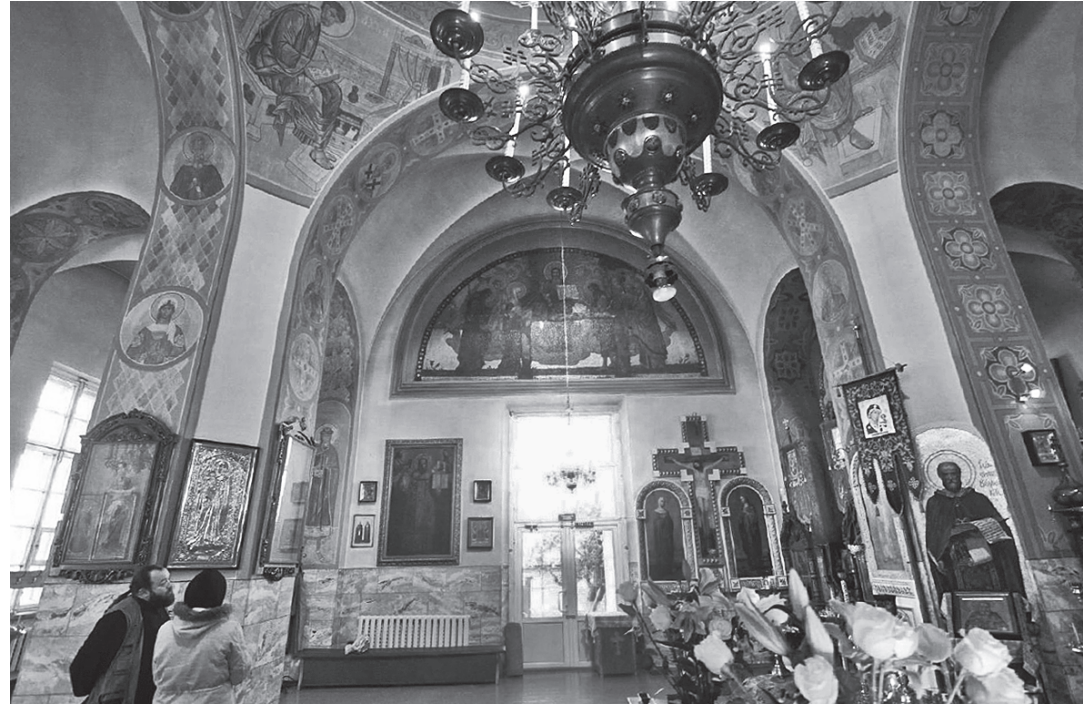

Fragmenty odtworzonych mozaik w cerkwi w Baranowiczach (fot. diakon Andrey Gorbunov).

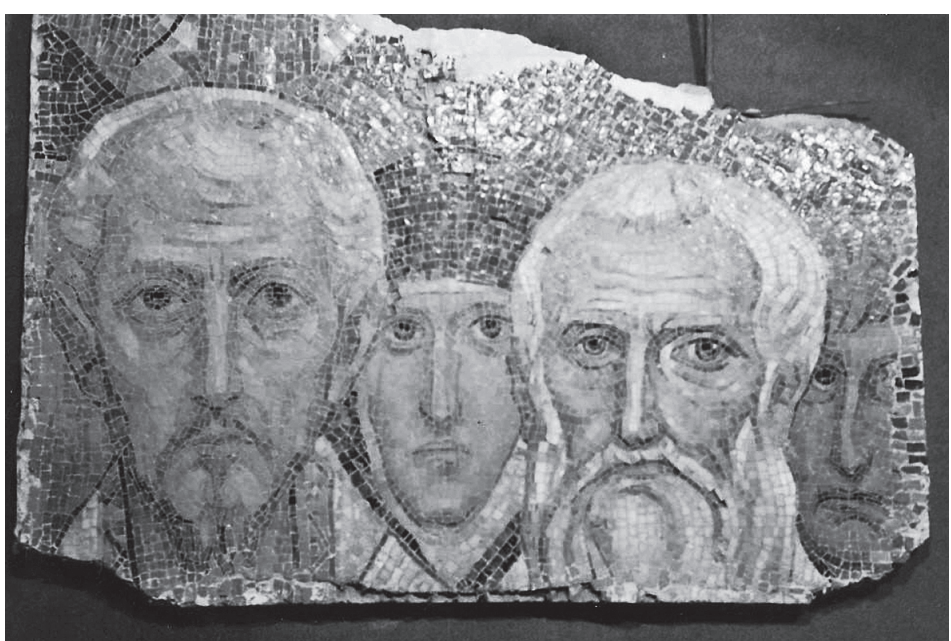

Fragment mozaiki znajdujacej sie $w$ zbiorach Muzeum Narodowego (fot. $d r$ Aleksandra Sulikowska-Betczkowska, archiwum prywatne).

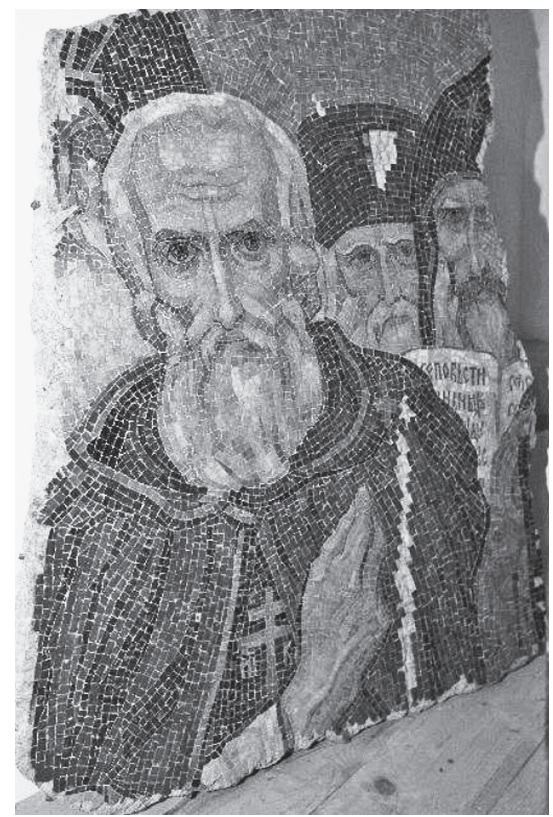

Fragment mozaiki znajdujacej się w cerkwi w Grodnie (fot. autor).
Czesść oltarzowa soboru po zorganizowaniu w nim światyni katolicko -protestanckiej-stan z około 1919 roku (ze zbiorów archiwum Warszawskiej Metropolii Prawostawnej).

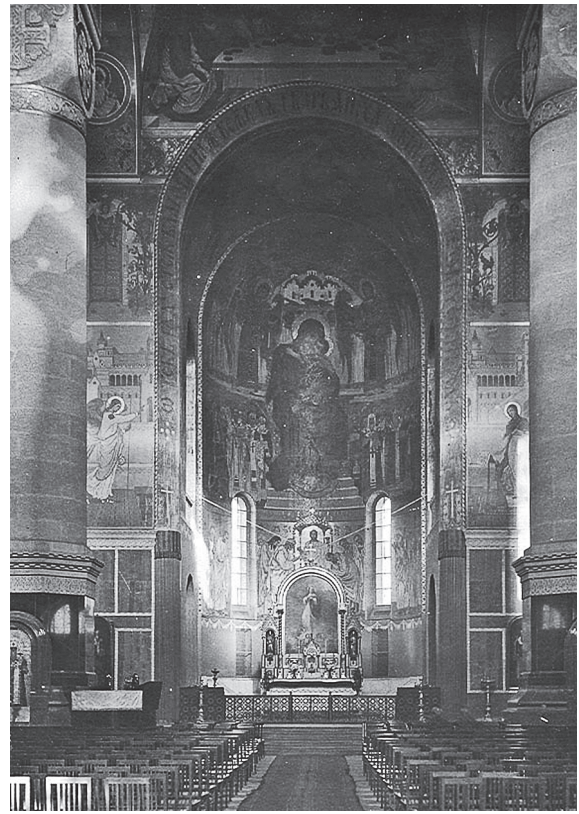


Niestety, zarówno dokumentujące poszczególne etapy rozbiórki soboru relacje medialne, jak i zachowana dokumentacja fotograficzna pokazują, iż zamierzenia tego nie zrealizowano. Z pokrywających ściany świątyni fresków - według posiadanej wiedzy - nie uratowano ani metra kompozycji. Przepiękne malowidła uległy nieodwracalnemu zniszczeniu, choć można je było zdjąć i umieścić chociażby w muzeum.

Wpływ na ten stan miał zarówno fakt - podnoszony wielokrotnie - wysokie koszty takiego działania, jak i sygnalizowane - jeszcze przed rozpoczęciem demontażu przez fachowców ze Związku Budowniczych Polskich - nieprzygotowanie merytoryczne. Zwłaszcza w sytuacji, gdy roboty zamierzano zlecić (i zlecono) przypadkowej grupie osób bezrobotnych. Zaznaczyć także należy, iż przeniesienie i zachowanie znacznej części fresków wykluczał - w 1924 roku - ich stan. Dokonane w latach wcześniejszych grabieże pokrycia dachowego skutkowały systematycznym zalewaniem ścian przez deszcze, nasiąkaniem ich i zagrzybieniem.

Nie zmienia to faktu, że można było zachować znaczne połacie zabytków sztuki ikonograficznej (freski).

Nieco inaczej rzecz się miała z mozaikami pokrywającymi: ściany części ołtarzowej, niektóre, mniejsze, elementy ścian bocznych oraz umieszczonymi nad wejściami do soboru. Tu stan zachowania nie budził zastrzeżeń, a sposób wykonania mozaik (poszczególne drobne elementy kamienne specjalnym klejem z elementami cementu umieszczono - w pracowni - na siatce, a dopiero tak powstały obraz cementowano do ściany w docelowej lokalizacji) powodował, iż ich demontaż - przy zachowaniu odpowiednich środków ostrożności - nie powinien nastręczać kłopotów. Wartość finansowa mozaik oraz ich „rzadkość” w porównaniu z freskami były również znacznie większe. Mimo to zdecydowana większość dzieł uległa zniszczeniu bowiem zdecydowano się na zachowywanie jedynie ich fragmentów - najczęściej samych twarzy. Zachowane zdjęcia dokumentujące burzenie soboru pozwalają względnie dokładnie określić, które elementy mozaik zostały przez niszczycieli wykrojone ze ścian. Niestety, w większości przypadków trudno dziś określić ich dalsze losy. Tak jak w przypadku elementów odnalezionych trudno ustalić sposób ich dostania się na aktualne miejsce ekspozycji.

Zdecydowanie największy fragment trafił do cerkwi Opieki Matki Bożej w Baranowiczach. Jak twierdzi dr hab. Mirosława Papierzyńska-Turek, można przypuszczać, iż jest to ten element, który pierwotnie przeznaczony został jako dar dla budującego się kościoła w Berlinie. Gotowy już do drogi, z nieznanych przyczyn, ,transport został zatrzymany na bocznicy kolejowej” (Papierzyńska-Turek, 1989, s. 357). Prawdopodobnie, w 1926 roku, przekierowany został finalnie do budowanego (po pożarze dotychczasowej drewnianej świątyni) według projektu Mikołaja Obołońskiego baranowickiego soboru w tym niewielkim, garnizonowym miasteczku na kresach Rzeczpospolitej (dziś Białoruś). Transport do Baranowicz miał zajmować trzy wagony (Ravâka, 2011). Zachowała się tu znaczna część mozaiki ołtarzowej, a także drobniejsze fragmenty dzieł umieszczonych pierwotnie w absydach soboru Newskiego i nad jego wejściami. Do Baranowicz trafiły także dwie portretowe mozaiki przedstawiające świętych Aleksego i Józefa stanowiące pierwotnie samodzielne kioty ustawione przy pierwszych (od ołtarza) kolumnach świątyni. Wszystkie te fragmenty stanowią dziś urzekającą dekorację białoruskiej świątyni (niewykorzystane fragmenty pieczołowicie zabezpieczono w pomieszczeniach parafialnych).

Niewielki fragment mozaiki można oglądać także w gmachu Wydziału Architektury Politechniki Warszawskiej przy ul. Lwowskiej. Przedstawiający głowy trzech postaci starotestamentowych pochodzi z części ołtarzowej soboru, tej, której zasadnicza część trafiła do cerkwi w Baranowiczach. Skąd wzięła się na Lwowskiej? Trudno dziś stwierdzić. Nie da się wykluczyć, że trafiła na Politechnikę przy okazji zaopatrywania tej uczelni w materiały budowlane wykorzystane przy budowie laboratoriów budowy maszyn (Przegląd Techniczny, 1923, s. 433). Można również zakładać, iż została „zagospodarowana” przez któregoś z pracowników Politechniki uczestniczących w pracach rozbiórkowych.

Fragmenty mozaik wycinane ze ścian soboru nie były ewidencjonowane, więc ich niekontrolowany ruch - zmiana właściciela - nie dziwi. Część trafiła do magazynów Muzeum Narodowego, a stamtąd - w latach osiemdziesiątych XX wieku do remontowanej dolnej cerkwi soboru metropolitalnego św. Marii Magdaleny na stołecznej Pradze (al. Solidarności 52). To fragmenty najpiękniejszego dzieła - projektu Wiktora Wasniecowa - Ostatnia Wieczerza. Niestety również i w tym przypadku zaniechano próby demontażu całego dzieła, poprzestając na - będącym de facto aktem wandalizmu - odcięciu i zachowaniu wyłącznie głów postaci Zbawiciela i Apostołów.

Dziś w Muzeum Narodowym znajduje się tylko jeden, niewielki, fragment soborowej mozaiki. Jak opisuje dr Aleksandra Sulikowska-Bełczowska, jest to - pozostający poza obiegiem ekspozycyjnym - fragment większej całości autorstwa Wiktora Wasniecowa przedstawiający ,oblicze świętego Ojca Kościola" (Sulikowska-Bełczowska). Został on skatalogowany jako otrzymany 18 maja 1928 roku dar Anny Brzezińskiej (Nr inw. IK 423 MNW). Można domniemywać, iż chodzi o żonę jednego z inżynierów nadzorujących burzenie soboru - zmarłego w tymże 1928 roku Stanisława Brzezińskiego.

Fragment mozaiki przedstawiający postaci świętych Sergiusza, Serafina i Nestora, a będący fragmentem kompozycji ołtarzowej, zobaczyć można w cerkwi pod wezwaniem świętych Borysa i Gleba w Grodnie. Niestety i w tym przypadku nie jesteśmy dziś w stanie stwierdzić, skąd się tu wzięly. Biorąc pod uwagę, iż świątynia ta w latach burzenia soboru i później była nieczynna (otworzono ją powtórnie w roku 1991) oraz fakt dość przypadkowego eksponowania zachowanego fragmentu (ustawiono go przy lewej, bocznej, ścianie świątyni w jej zachodnim krańcu) nie ulega wątpliwości, iż znajdować się musiała przez blisko 100 lat w innym miejscu. 


\section{Ruchomy wystrój wewnętrzny}

Jeszcze trudniejsze jest odtworzenie losów ruchomego wyposażenia soboru, choć to właśnie ono budzi największe zainteresowanie i to ono staje się bohaterem większości związanych z katedrą miejskich legend. Nie zapominajmy, że było to mienie wielkiej wartości zarówno artystycznej, jak i finansowej.

Opisując wnętrze soboru na potrzeby czytelników „Gazety Świątecznej”, w maju 1919 roku członek kółka rolniczego, rolnik spod Kutna, Antoni Pachnowski pisze: „Bogactwa żadnego tam nie widziatem; byto podobno ogromne, ale Niemcy zabrali, co miato większa wartość, czyli inaczej mówiąc, skradli" (Pachnowski, 1919, s. 3). Czy jednak rzeczywiście Niemcy? I czy wszystko?

Już bowiem Rosjanie opuszczając Warszawę, metodycznie zabierali wszystko, co stanowić mogło jakąkolwiek wartość. W ten sposób Warszawę opuściło nie tylko wyposażenie większości fabryk, ale także inwentarz Zamku Królewskiego, Biblioteki Uniwersytetu Warszawskiego czy prawie całe zbiory archiwów państwowych.

W swej relacji z tego czasu Marianna Sorwina pisze: „W zbudowanej stosunkowo niedawno katedrze Aleksandra Newskiego znajduja się tylko ściany z freskami i mozaikami. Naczynia kościelne, ikonostas, ikony i szaty zabrali rzemieślnicy wysłani z Moskwy" (Sorwina 2014). Również „Kurjer Warszawski” krótko po opuszczeniu Warszawy przez Rosjan odnotowywał: „Sobór prawosławny na pl. Saskim władze okupacyjne zajęty na świqtynię dla wojska. Sobór rosjanie sami ogołocili w lipcu r. z." (Kurjer Warszawski, 72 1916, s. 3). Opis ten zgadzałby się z ogólnymi zasadami ewakuacji opracowanymi przez oberpolicmajstra Piotra Meyera we wrześniu 1914 sprowadzającymi się w istocie do jednej zasady: zabrać co się da.

Tyle że w roku 1921 varsavianista i autor poczytnych książek Mieczysław Orłowicz opisując praską katedrę św. Marii Magdaleny, pisze: „Obecnie jest cerkiew dość zaniedbana, a wewnątrz robi wrażenie rupieciarni dzięki temu, że z wyjątkiem wazkiego przejścia środkiem zajmuja ja w całości obrazy, oltarze, i części ikonostasu z dawnego soboru na Placu Saskim, ponarzucane jedne na drugich" (Orłowicz 1922, s. 123). Dzięki zachowanemu protokołowi z przekazania - zajętej po odzyskaniu niepodległości przez władze cywilne - Kościołowi Prawosławnemu cerkwi praskiej wiemy, iż przedmiotów tych w roku 1919 w świątyni nie było. 17 kwietnia 1919 roku środek zajmowały bowiem ,lawki drewniane z żelaznemi nogami $w$ ilości trzydziestu pięciu i sześć tawek zwyczajnych" (Archiwum Akt Nowych, zb. 1205 k. 187). Składowane wyposażenie musiało trafić tu więc około roku 1920 lub później. Trudno więc zakładać, by naprawdę pochodziło z soboru na Placu Saskim. Świątynia ta była już wówczas od dwóch lat wykorzystywana do nabożeństw katolickich i trudno zakładać, by dokonywano w niej istotnych grabieży. Warto jednak pamiętać, iż w okresie tym zamknięto w samej Warszawie kilkanaście prawosławnych świątyń różnej wielkości i prawdopodobnie stąd pochodziły skła- dowane na Pradze przedmioty. Zupełnie nieświadomie Orłowicz stał się więc autorem pierwszej miejskiej legendy o wyposażeniu soboru ${ }^{1}$.

\section{Ikonostas}

Zwróćmy uwagę, że zarówno relacja Sorwiny, jak i Orłowicza wspomina o ikonostasie. Kiedy więc w istocie z soboru zniknął ikonostas? Zdania na ten temat są podzielone. Anonimowy dziennikarz w roku 1924 twierdził: „Ikonostas mozaijkowy z ornamentacjami artysty Rajlana wywieźli Niemcy, a owe mozaiki sa fabrycznego pochodzenia" (Legenda o skarbach sztuki w soborze, 1924, s. 3). Cytowany już Antoni Pachnowski zwiedzając świątynie w roku 1919, odnotowuje jedynie, iż „Sa teraz trzy tymczasowe katolickie ottarze: wielki, przed którym goreje lampka, gdyż tam jest N. Sakrament, i dwa obok; sq też $i$ organy" (Pachnowski, 1919, s. 3). Ten drugi fakt nie budzi wątpliwości. W zamienionej na świątynię garnizonową katedrze organizowano nabożeństwa dla żołnierzy katolików i protestantów. Przy czym - zgodnie z wolą ówczesnego arcybiskupa warszawskiego Aleksandra Kakowskiego w pierwszej kolejności odbyć się tam miały nabożeństwa protestanckie, a dopiero potem konsekracja na potrzeby katolików². Gdy 25 lutego 1916 roku niemiecki biskup Heinrich Joeppen dokonywał poświęcenia zmienionego w kościół św. Henryka soboru, gazety zauważały, iż „Kościót na placu Saskim ulegt pewnym przeróbkom. W nawie glównej ustawiono oltarz z obrazem Niepokalanego Poczęcia NMP, a po lewej stronie urządzono kazalnice" (Poświęcenie kościoła na Placu Saskim, 1916, s. 5). Ani słowem nie wspominają jednak o demontażu ikonostasu? Czyżby więc rzeczywiście nie było go już w chwili zajmowania Warszawy przez Niemców? Co się zatem z soborowym ikonostasem stało? I tu dochodzimy do kolejnej $\mathrm{z}$,miejskich legend”.

Na licznych stronach internetowych opisujących cerkiew św. Szymona Słupnika w Kamieńsku (Hram prepodobnogo Simeona Stolpnika v g. Kamence, 2019) na Białorusi przeczytać można, iż znajduje się w nim ikonostas pochodzący z „,warszawskiego soboru św. Aleksandra Newskiego". Informację tę znaleźć można także w poważnych materiałach źródłowych (m.in. Kulagìn, 2001, s. 96). Czy jest prawdziwa? Wystarczy spojrzeć na zachowane zdjęcia (a ocalały - choć pojedyncze - ujęcia dokumentujące wszystkie trzy ikonostasy z soboru), by mieć pewność, że ten w Kamieńcu nigdy na Placu Saskim nie stał. Skąd więc naprawdę pochodzi białoruski ikonostas? Czy po latach można do końca odczarować tę miejską legendę?

1 Oczywiście nie możemy wykluczyć, że jakieś ikony z cerkwi na placu Saskim znajdowały się wówczas w praskiej świątyni a Orłowicz, źle poinformowany, odniósł ten fakt do wszystkiego co w niej ujrzał.

2 Decyzja abp. Kakowskiego wynikała z wyraźnie artykułowanej obawy przed powrotem do Warszawy Rosjan wobec niestabilnej wciąż sytuacji na froncie. Pierwsze nabożeństwo ewangelickie w gmachu soboru odbyło się 8 sierpnia 1915 roku. 

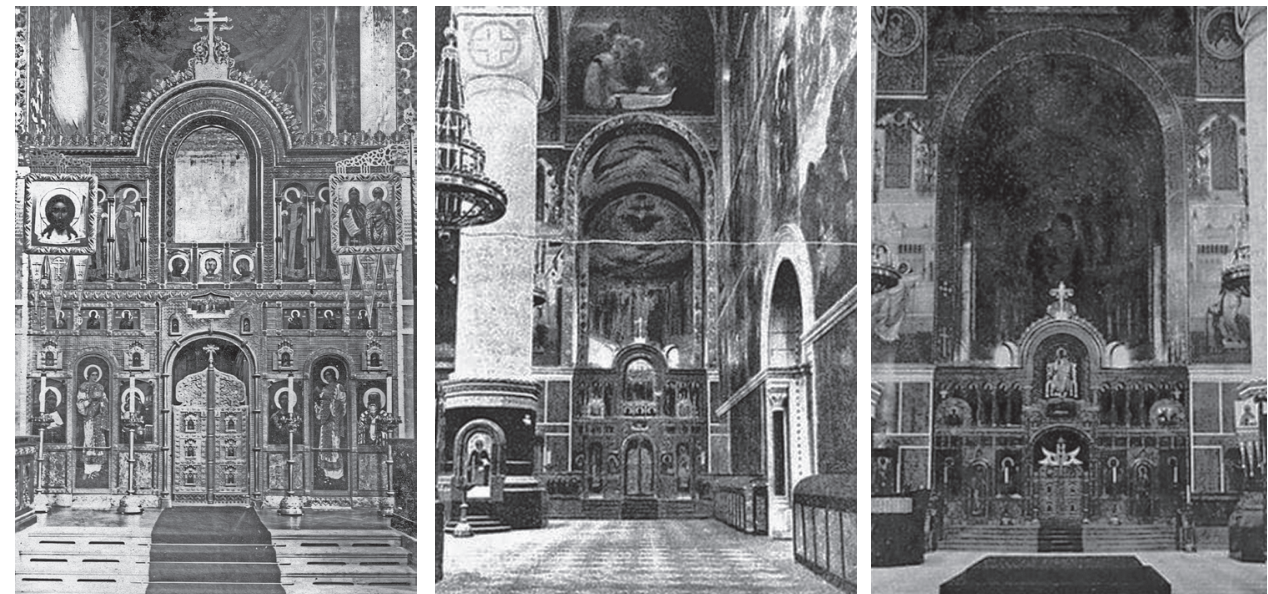

Ikonostasy soboru św. Aleksandra Newskiego w roku 1913 (ze zbiorów archiwum Warszawskiej Metropolii Prawosławnej).

Spróbujmy dla dalszego badania przyjąć metodę „Śledczych przybliżeń” wraz z założeniem pierwotnym, iż ikonostas do Kamieńca naprawdę przyjechał z Warszawy. Może więc w istocie pochodził ze stołecznej świątyni poświęconej księciu nowogródzkiemu, ale nie tej, o której wspomina legenda? Niewiele bowiem osób dziś już pamięta, iż św. Aleksandrowi Newskiemu poświęcono w Warszawie jeszcze dwie inne, wcześniejsze od Soboru, cerkwie. Pierwszą z nich była ta zlokalizowana w Cytadeli. Zbudowano ją w latach 1834-35 według projektu Andrzeja Gołońskiego $^{3}$. Opisując uroczystość poświęcenia świątyni, „Kurjer Warszawski” odnotowuje jedynie, iż: „Nowa Cerkiew Sgo Alexandra Newskiego wystawiona iest wedtug ogólnego modelu dla wszystkich naszych Cerkwi w twierdzach, ma bardzo piękna powierzchowność, i może mieścić $w$ sobie do 1,200 ludzi. Ottarz wielki $i$ wewnętrzne upiększenia, odznaczaia się również wytworna robota" (Kurjer Warszawski, 329 1835, s. 1).

Nieco dokładniejszy opis znajdujemy w wydanym w roku 1873 ,Przewodniku po Warszawie i jej okolicach na rok 1873/4 z mappą miasta, Mappami Kolei Żelaznych i drzeworytami". Tu autorzy pokusili się o jednozdaniowy opis ikonostasu: „Ma Ikonostas z obrazami na płótnie malowanemi w Akademii Sztuk Pięknych $w$ Petersburgu, w skład którego wchodza środkowy Zbawiciela i Matki Boskiej, po obu zaś stronach św. Mikołaja i Aleksandra Newskiego" (Fryze, Chodorowicz, 1873, s. 17).

Sądząc po powyższym opisie, założyć by można, że ikonostas w Cytadeli był jednopiętrowy - wskazują na to także stosunkowo niewielkie rozmiary świątyni mającej zaledwie 17 metrów w najszerszym miejscu. Niestety zdjęcia cerkwi nie zachowały się. O jej wyglądzie możemy wyciągać wnioski, oglądając fotografie bliźniaczej świątyni w Modlinie (Prawosławne cerkwie na starych pocztówkach, 2019).

I tu przychodzi zaskoczenie. Wśród innych pocztówek jest bowiem także zdjęcie przedstawiające ikonostas świątyni w Modlinie... dwupiętrowy. Notabene sądząc po sto-

\footnotetext{
Według tego samego projektu w latach 1835-1837 został wzniesiony sobór św. Jerzego w Modlin
}

jącej centralnie fisharmonii, zdjęcie powstało po odebraniu cerkwi Prawosławnym (Prawosławne cerkwie na starych pocztówkach, 2019).

Źródła milczą, w jakim stopniu wystrój wewnętrzny obu świątyń (tej w Cytadeli w Warszawie i w twierdzy w Modlinie) był podobny - nie ulega jednak wątpliwości, biorąc pod uwagę wielkość ikonostasu w Kamieńcu, iż nie pochodzi on z Cytadeli.

Może zatem z drugiej świątyni poświęconej św. Aleksandrowi? Sięgnijmy jeszcze raz do Przewodnika po Warszawie. Tak opisuje on cerkiew urządzoną w Pałacu na Wodzie w Łazienkach: „Cerkiew nadworna pod wezwaniem $S$. Aleksandra Newskiego, przy pałacu Cesarskim w Lazienkach. Wystawiona $w$ roku 1846 z zastosowaniem $w$ guście całości łaczacego się z nim gmachu pałacowego, podtug planu Andrzeja Gołońskiego. Światynia niewielka, ale bardzo piękna i bogato ozdobiona, ma ściany i sufit marmoryzowane na biało. Ikonostas bardzo piękny o dwóch piętrach z drzewu lipowego, bogato rzeźbiony i złocony mieści obrazy pierwszorzędnych artystów ruskich. Z tych $w$ niższem piętrze wyobrażaja główne Zbawiciela i Matkę Boska, na potudniowych drzwiach św. Aleksandra i św. Aleksandra Newskiego, na pótnocnych: świętych Pawła i Mikołaja. Na carskich wrotach czterech ewangelistów, w środku Najświętsza Panna i Gabryel archaniot. W piętrze wyższem nad wrotami carskiemi Wieczerza Pańska, nad nia trzech aniołów, po prawej stronie której Magdalena, św. Konstantyn, po lewej św. Olga i Michat Archaniol. $W$ średniej części cerkwi umieszczone sa obrazy: po prawej stronic Cesarz Konstantyn, po lewej Michat Archaniot. Ze wszystkich atoli szczególna zwraca na siebie uwage obraz zawieszony nad ottarzem, wyobrażajacy Zbawiciela modlacego się w ogrodzie Getssmańskim arcydzieło znakomitego malarza Karola Brudowa. Podobnież znajduja się tu odpowiednio wspaniałe i sprzęty kościelne" (Fryze, Chodorowicz, 1873, s. 17-18).

Przyjrzyjmy się więc jeszcze raz ikonostasowi z Kamieńca. I oto mamy „Na carskich wrotach czterech ewangelistów, w środku Najświętsza Panna i Gabryel archaniol”. Zgadza się również, iż „W piętrze wyższem nad wrotami carskiemi Wieczerza Pańska” - co nie jest spe- 
cjalnie trudne, wynika bowiem wprost z cerkiewnej tradycji. Dalej jednak powinniśmy mieć: ,, nad niq trzech aniotów, po prawej stronie której Magdalena, św. Konstantyn, po lewej św. Olga i Michat Archaniol”. Tymczasem w Kamieńsku mamy scenę Zmartwychwstania Pańskiego.

A więc i ten trop okazuje się chybiony. Zwłaszcza, iż ikonostas z Łazienek był lipowy, a w Kamieńsku mamy dębowy.

Skoro więc nie z „Aleksandra Newskiego" to skąd? Nowy trop daje nam autor strony opisującej historię kamieńskiej świątyni, pisząc: „Symeon Pawłowicz (...) dzięki swoim talentom organizacyjnym byt $w$ stanie $z$ sukcesem zorganizować zakup nowego ikonostasu z dębu bagiennego, który byt przechowywany $w$ rosyjskim gimnazjum w Warszawie" (Simeonovskaâ cerkov'v Kamence, 2020).

Szkoła taka, posiadająca własną kaplicę była w Warszawie jedna. Oto w 1862 roku w budynku rozwiązanego Towarzystwa Królewskiego Warszawskiego Przyjaciół Nauk zwanym Pałacem Staszica władze carskie postanowiły uruchomić Pierwsze Gimnazjum Męskie, powszechnie zwane „ruskim”, wraz z internatem. Szkoła dysponowała własną kaplicę pod wezwaniem świętych Cyryla i Metodego. Zlokalizowano ją początkowo na drugim piętrze pałacu, a następnie przeniesiono do nieco większego pomieszczenia na piętrze pierwszym.

Ze względu na potrzebę pilnego uruchomienia świątyni, biskup Leontyn polecił przeniesienie „ikonostasu oraz innych elementów wyposażenia" (Cvetaev, 1898) ze zlikwidowanego rok wcześniej Instytutu Wychowania Panien w Nowej Aleksandrii (dziś Puławy). Ze względu na wielkość zajmowanych pomieszczeń wykluczyć można z góry, by chodziło o ikonostas znajdujący się dziś w Kamieńsku. Wskazuje na to także (skromny) opis świątyni umieszczony przy okazji jej poświęcenia przez Cholmsko-Varsavskij Eparchialnyj Vestnik (Cholmsko-Varsavskij Eparchialnyj Vestnik, 1878, s. 6-8).

Zwiększające się potrzeby wymusiły powiększenie świątyni. W 1891 roku zapada decyzja, a w 1892 roku rusza przebudowa Pałacu Staszica - w stylu bizantyjsko -ruskim (zakończona w 1893) według projektu rosyjskiego architekta Michaiła Pokrowskiego. Dla upamiętnienia rosyjskiej przeszłości tego miejsca ulokowano tu z inicjatywy i dzięki staraniom Aleksandra Apuchtina, kuratora Okręgu Naukowego Warszawskiego, cerkiew św. Tatiany Rzymianki. Znaczna część warszawiaków wciąż nazywała budynek „ruskim gimnazjum”, co mogłoby być powodem sądu, iż pochodzący stąd ikonostas jest z „męskiego gimnazjum”. Może więc ikonostas pochodzi stąd?

3 marca 1919 roku uchwałą Magistratu miasta stołecznego Warszawy nr 5062 powołano specjalną komisję w składzie:

- prof. Mikołaj Tołwiński - architekt, autor m.in. kaplicy Karola Scheiblera w Łodzi

- Teofil Wiśniowski - konserwator (zabytków) okręgu warszawskiego powołany przez Ministra Sztuki i Kultury

- Józef Pius Dziekoński - architekt, autor projektów blisko 100 kościołów katolickich
- Karol Jankowski - architekt, autor projektów kilkudziesięciu gmachów użyteczności publicznej

- Cezary Przybylski - architekt, autor m.in. projektu Dworca Głównego w Warszawie oraz wyróżnionego II nagrodą projektu Świątyni Opatrzności w Al. Ujazdowskich

- Juliusz Dzierżanowski - p.o. zarządzającego wydziałem budownictwa Magistratu, architekt, autor m.in. Hali Koszyki czy kamienicy „Pod Messalką”

- Stefan Szyller - kierownik sekcji drugiej budowli miejskich wydziału budownictwa Magistratu

- Wincenty Kasprzycki - radca prawny Magistratu.

Jej zadaniem było dokonanie oceny co do dalszego losu blisko 30 świątyń prawosławnych zlokalizowanych na terenie Warszawy (bądź jako samodzielne budynki, bądź jako kaplice domowe). Komisja dokonała wizji lokalnych wszystkich obiektów. Niestety, nie zachowały się dokumenty robocze Komisji, nie wiadomo więc, jak wyglądały jej prace. A byłaby to wiedza niezwykle cenna, biorąc pod uwagę, iż żaden z członków gremium nie miał jakiegokolwiek doświadczenia związanego z prawosławną sztuką sakralną.

20 września 1919 roku Wydział VII budownictwa Magistratu Miasta Stołecznego Warszawy pismem nr 2484. VII.I przekazał Ministerstwu Wyznań i Oświecenia Publicznego „Protokół Komisji Kwalifikacyjnej w sprawie cerkwi istniejących w Warszawie". W dokumencie (str. 8) można przeczytać:

„16/ Cerkiew w pałacu Staszica. Mieści się na II piętrze, jest sklepiona 3-ma przedziałami opracowana dekoracyjnie w stylu moskiewskim. Zdaniem komisji winna być $w$ czasie najbliższym rozebrana lub przebudowana jednocześnie z przebudowa całej przedniej części tego gmachu podlug projektu rekonstrukcyjnego dawnego gmachu Towarzystwa przyjaciót nauk z zachowaniem dawnej pięknej elewacji pomystu Corazzi'ego. Ikonostas, obrazy it.p. komisja proponuje zmagazynować dla ewentualnego zwrotu rządowi rosyjskiemu"

Decyzja Komisji w tym zakresie miała charakter raczej symboliczny, biorąc pod uwagę, iż już 26 lipca 1919 roku Sejm Ustawodawczy podjął uchwałę o przeznaczeniu całego budynku na rzecz Warszawskiego Towarzystwa Naukowego. Dla nas ważnym jest jednak, że ikonostas proponuje się złożyć w magazynie.

W Archiwum Akt Nowych nie ma dokumentów poświęconych likwidacji cerkwi św. Tatiany, ale można z dużą dozą pewności założyć, iż jesienią 1920 roku ikonostas już nie istniał. Pomieszczenia świątyni zostały bowiem zmienione na główną salę posiedzeń. W tej zaś, jak donosił „Kurier Warszawski”: „odbyto się wczoraj uroczyste doroczne zebranie. Piękna sale zebrań przybrano we wspaniałe dywany i kilimy, kryjąc nimi pozostatości wschodnie po przejściowych, za czasów niewoli Polski, gmachu tego posiadaczach. Dostojne a liczne grono osób zaproszonych przybyło, jak zazwyczaj, w strojach wieczorowych. Przed prezydialnym stotem trzy fotele zajęli: Naczelnik Państwa Józef Pitsudski, Jego Eminencja ksiądz kardynat Aleksander Kakowski i marszatek pierwszego Sejmu suwerenne- 
go Wojciech Trampczyński. (...) Stót prezydialny miat za tło ścianę zieleni cieplarnianej, pośród której ustawiono marmurowe popiersie fundatora gmachu, wiekopomnego Stanistawa Staszica."

Daty wskazują więc na to, iż ikonostas kamieński mógł przyjechać z Pałacu Staszica. Niestety, przeczy temu... ikonografia. Ocalało bowiem zdjęcie ikonostasu z cerkwi św. Tatiany, które nie pozostawia złudzeń. A więc i ten trop jest fałszywy.

To tylko jeden przykład fascynującej, ale wciąż nierozwikłanej zagadki, u której początku znajduje się Sobór św.
Aleksandra Newskiego na stołecznym Placu Saskim. Na swoje dochodzenia czekają kolejne elementy wyposażenia mające - według podania - pochodzić ze zburzonej świątyni. Są wśród nich zarówno ogromne obrazy - jak choćby ten w kaplicy w podwarszawskim Międzylesiu określany jako „ikona z soboru”, jak i nieliczne paramenty otoczone legendą ,tego soboru” (na przykład kielich liturgiczny pozostający w dyspozycji arcybiskupa wrocławsko-szczecińskiego). W każdym z tych przypadków łatwiej jednak będzie wykluczyć związek ze zburzoną świątynią niż wskazać prawdziwą historię i drogę, jaka odbyły na współczesne miejsce pobytu.

\section{Bibliografia}

290 robotników robi dziennie 150 dziur w soborze. (1926). Kurjer Poranny. 6 marca 1926. nr 65.

Cholmsko-Varsavskij Eparchialnyj Vestnik. (1878). 1878.11.15 (27) R. II. Nr 22.

Express Poranny.(1927). 14 sierpnia 1927. nr 274.

Historia jednego podwórka. (1926). Express Poranny. 15 stycznia 1926. nr 16.

Hram prepodobnogo Simeona Stolpnika v g. Kamence. (2019). [online] www.kamlib.by/literary_district/monuments/Cerkov\%D1\%8C\%20Kamenec.php, [7.04.2019].

Kurjer Polski. (1902). 9 listopada 1902. nr 311.

Kurjer Poranny. (1926). 27 lipca 1926. nr 206.

Kurjer Poranny. (1929). 2 maja 1929. nr 120.

Kurjer Warszawski. (1835). nr 329.

Kurjer Warszawski. (1916), 12 marca 1916. nr 72.

Kurjer Warszawski. (1923). 21 listopada 1923. nr 320.

Kurjer Warszawski. (1927). 21 listopada 1927. nr 320.

Kurjer Warszawski. (1929). 15 lutego 1929. nr 45.

Kurjer Warszawski. (1934). 13 kwietnia 1934. nr 100.

Legenda o skarbach sztuki w soborze. (1924). Przegląd Wieczorny. 21 lutego 1924. nr 43.

Monitor Polski. (1923). nr 49.

Orzeł Biały. (1925). 8 listopada 1925. nr 45.

Prawosławne cerkwie na starych pocztówkach. (2019). [online] www.chram.com.pl, [7.04.2019.]

Projekt kościółka. (1924). Kurjer Poranny. 10 lutego 1924. nr 40.

Podstępna sprzedaż domu zbudowanego z cegieł soboru. (1935). Warszawski Dziennik Narodowy. 16 lipca 1935. nr 50.

Poświęcenie kościoła na Placu Saskim. (1916). Kurjer Polski. 26 lutego 1916. nr 57.

Przegląd Techniczny. (1923). 12 października 1923. nr 41-42.

Przegląd Wieczorny. (1926). 4 marca 1926. nr 51.

Simeonovskaâ cerkov'v Kamence. (2020). [online] www.kamenets.by/simeonovskaya-tserkov-v-kamentse, [7.04.2020].

Sprawozdanie stenograficzne ze 152 posiedzenia Sejmu Ustawodawczego z dnia 1 czerwca 1920 roku (2020) [online] http://dlibra.umcs.lublin.pl/dlibra/publication/7519E. [27.05.2020].
Sprawozdanie z działalności Zarządu m.st. Warszawy za rok 1926 i I kwartat 1927 (1928). Warszawa.

Cvetaev, D. V. (1898). Zapiska o domovoj cerkvi Varšavskoj pervoj mužskoj gimnazii. Varšava [Цветаев, Д. В. (1989). Записка о домовой иеекви Варшавской первой мужской гимназии, Варшава].

Fryze, F., Chodorowicz, I. (1873). Przewodnik po Warszawie i jej okolicach na rok 1873 i 1874, z mapa miasta, mapami kolei żelaznych i drzeworytami, ułożony $i$ wydany. Warszawa.

Kulagìn, A. M. (2001). Pravaslaǔnyâ hramy na Belarusì. Èncykl. daved. Mn.: Belèn, 2001. [Кулагін, А. М. (2001) Праваслаўныя храмы на Беларусі. Энцыкл. давед. Мн.: БелЭн].

Orłowicz, M. (1922). Krótki ilustrowany przewodnik po Warszawie. Warszawa: Wydawnictwo PTK.

Pachnowski, A. (1919). Nie burzyć, ale budować. Gazeta Świqteczna. 4 maja 1919. nr 1996.

Papierzyńska-Turek, M. (1989). Między tradycja a rzeczywistością. Państwo wobec prawosławia 1918-1939. Warszawa.

Paszkiewicz, P. (1991). Pod bertem Romanowów. Sztuka rosyjska $w$ Warszawie 1815-1915. Warszawa.

Paszkiewicz, P. (1999). W stużbie Imperium Rosyjskiego 17211917. Funkcje i treści ideowe rosyjskiej architektury sakralnej na zachodnich rubiezach Cesarstwa i poza jego granica$m i$. Warszawa.

Ravâka R. (2011). Hram, adrodžany ǔ Baranavičah. Intexpress [Равяка Р. (2011). Храм, адроджаны ў Баранавічах. Intexpress].

Sokoł, K. (2006). Rosyjska Warszawa. (A. Sosna, Tłum.). Białystok.

Sorwina, M. (2014). Varšava v kol'ce. W: Znanie-Sila, 11/2014 [Sorwina, M. (2014). Варшава в кольце. W: Знание-Сила, 11/2014].

Sulikowska-Bełczowska, A. (b.r.w.). Losy zabytków sztuki cerkiewnej w Rzeczypospolitej po odzyskaniu niepodległości. W: Stan badań nad wielokulturowym dziedzictwem dawnej Rzeczypospolitej-maszynopis. Archiwum prywatne autora.

Wachowicz, B. (1975). Ziemia uroczna Stefana Żeromskiego. Kraków: KAW. 